\title{
EFFECT OF ZONE AND CROPS ROTATION ON Ischaemum rugosum ANd Resistance to Bispyribac-Sodium in ARIARI, Colombia ${ }^{1}$
}

\author{
Efeitos em Zonas e Rotação das Culturas do Ischaemum rugosum e sua Resistência ao \\ Bispiribac-Sódio em Ariari, Colômbia
}

PLAZA, G. ${ }^{2}$ and HERNÁNDEZ, F.A.

\begin{abstract}
The objectives of this research were to evaluate (1) weed species presented in rice fields in relation to the geographical zone and crop rotation and (2) the resistance level of Ischaemum rugosum to the herbicide bispyribac-sodium. For the first objective, were sampled 79 commercial fields of rice to establish weed density, coverage, and rotation system in the evaluated fields with record of bispyribac-sodium application of at least five years. To reach the second objective, the seeds were collected from plants in commercial fields with different control levels of bispyribac-sodium herbicide. Seeds were germinated in trays under controlled conditions. When plants presented three leaves these were treated with bispyribac-sodium at different doses. Percentages of control and dry weight of plants were evaluated 12 days after treatments (dat). Dominant species in evaluated fields was I. rugosum, with a frequency of $100 \%$, presenting escapes to different chemical commercial treatments. No significant differences were recorded between rotation systems, nevertheless, the most of I. rugosum population was found in the system rice-fallow-rice. The response of applications at different concentrations allows concluding that $65 \%$ of samples had resistance at different degrees reported as indexes from 2 to 42 which are related to rotation systems.
\end{abstract}

Keywords: wrinklegrass, rice weeds, resistance index, ISCRU.

RESUMO - O objetivo desta pesquisa foi (1) avaliar as espécies de ervas encontradas nos campos de arroz com relação à zona geográfica e à rotação das culturas e (2) o nível de resistência de Ischaemum rugosum ao herbicida bispiribac-sódio. No primeiro objetivo, foram amostrados 79 campos comerciais de arroz, visando estabelecer a densidade, a cobertura e a rotação do sistema de plantas daninhas nos campos avaliados, com a aplicação de bispiribac-sódio por pelo menos um periodo de cinco anos. Para alcançar o segundo objetivo, as sementes foram coletadas de plantas de campos comerciais sob diversos niveis de controle do herbicida bispiribac-sódio. As sementes foram germinadas em bandejas sob condições controladas. Quando as plantas tinham três folhas, foram tratadas com diferentes doses de bispiribac-sódio. Porcentagens de controle e peso seco das plantas foram avaliadas 12 dias após tratamento (DAT). A espécie dominante nos campos avaliados foi I. rugosum, com frequência de 100\%, apresentando resistências a diversos tratamentos comerciais quimicos. Não foram registradas diferenças significativas entre os sistemas de rotação, porém a grande maioria de $\mathbf{I}$. rugosum foi encontrada no sistema arroz-cultivo-arroz. A resposta em aplicações com diferentes concentrações permite concluir que 65\% das amostras mostraram resistência em diversos niveis, conforme relatado nos indices de 2 a 42, que estão relacionados com os sistemas de rotação.

Palavras-chave: ervas enrugadas, plantas daninhas do arroz, índice de resistência, ISCRU.

1 Recebido para publicação em 13.9.2013 e aprovado em 25.4.2014.

2 Universidad Nacional de Colombia, Bogotá, Cundinamarca, Colombia. <gaplazat@unal.edu.co>; ${ }^{3}$ Federación Nacional de ArrocerosFedearroz, Granada, Meta, Colombia. 


\section{INTRODUCTION}

In Colombia, the largest rice-planted region is Llanos Orientales with approximately 155,400 ha $(32 \%$ of area), composed by the provinces Arauca, Meta, and Casanare. Meta provides $50 \%$ of the rice-planted area in Llanos Orientales, representing a large share of the national market, with productivity between 5.3 and 5.8 ton ha ${ }^{-1}$ (FEDEARROZ, 2009). Ariari region dedicates around 20,000 ha to rice crop per year in three differenced geographic zones, around the Ariari River. The zone 1 is located on the left bank of this river, reaching an altitude between 0 and $5 \mathrm{~m}$ related to the river's level; therefore, this zone is the most flood-prone area, showing as well flat topography, low levels of terrace, usually good drainage, pH5.6 soil and loam sandy. As the first zone, the zone 2 is located at the left bank of Ariari river with an altitude between 6 and $10 \mathrm{~m}$ above the river's level and is less prone to flooding, showing slopes of less than 3\%, good drainage, pH5.0 soil and sandy texture (Vanegas et al., 1998). The zone 3 is located at the right bank of Ariari River, with an altitude between 2 and $35 \mathrm{~m}$ above the river's level and less prone to flooding, has pH4.9 soil, loam clay texture and usually good drainage (Rippstein et al., 2001).

For this region and other producing areas of the country, weed competition is the rice production main constraint (FEDEARROZ, 2009). Weed management implemented in the zone showed high dependence on chemical control, including the use of propanil, fenoxaprop-ethyl, profoxydim, sulfonylurea, and bispyribac-sodium.

The most important feature that affects the evolution of a species weed resistance to herbicide is the selection pressure exerted by the herbicide (Jasieniuk et al., 1996). The highest selection pressure is exerted using high doses with highly effective, persistent and frequently applied herbicides (Mortensen et al., 2000; Reznick \& Cameron, 2001). At the beginning, Ischaemum rugosum management with bispyribac-sodium were satisfactory; farmers preferred this herbicide use to other alternatives because of its crop selectivity, high efficiency, versatility, and application in low doses, treating more than $90 \%$ of the total area with this herbicide. It resulted, during the last five years that farmers and technicians began to detect fields with $I$. rugosum populations, resistant to bispyribac-sodium.

In order to determine the resistance's issue in Ariari region, the objective of this research was to establish the geographical area and the crop rotation effects on I. rugosum populations, and assess the resistance's degree of I. rugosum populations to bispyribacsodium herbicide in the Ariari region.

\section{MATERIALS AND METHODS}

This research was conducted in the municipalities of Granada $\left(3^{\circ} 32^{\prime} 42^{\prime \prime} \mathrm{N}\right.$ and $\left.73^{\circ} 42^{\prime} 33^{\prime \prime} \mathrm{W}\right)$, with an altitude of 332 m.a.s.1. and Fuente de Oro ( $3^{\circ} 28^{\prime} 7^{\prime \prime} \mathrm{N}$ and $\left.73^{\circ} 36^{\prime} 54^{\prime \prime} \mathrm{W}\right)$, with an altitude of 293 m.a.s.1, with an average annual temperature of $25^{\circ} \mathrm{C}$, and average rainfall of 2,600 $\mathrm{mm}$ for both municipalities, which are representative of the Ariari rice area with $70 \%$ of sown area in the region.

The experiment consisted of two stages: thefirst one took place on 79 rice fields' assessments, where frequency, density and coverage of rice, I. rugosum, and other weed species were recorded during the crop cycles. In addition, the crop rotation type on each field and zone in which it was located, according to the Ariari region classification. The number of sampled fields per zone was distributed according to the participation area percentage according to the region, with 13 fields for zone 1, 10 fields for zone 2 and 56 fields for zone 3. In each field, a representative area of approximately one hectare with three random sample points, using quadrants of $0.25 \mathrm{~m}^{2}$ was selected. Determination of differences between the geographical zones and the crop rotation management was based on weed population's data analysis, consisting of variance and comparison analysis, using General Linear Model (GLM) of SAS program procedures.

The second stage consisted of I. rugosum population's resistance assessment to bispyribac-sodium herbicide with seeds from fields with application records of minimum five years and its relation to the geographical zone and rotation type. I. rugosum mature seed were collected in rice fields' plots that had been 
monitored in the previous phase. Additionally, I. rugosum seeds were collected from a plot that had not been planted with rice during the last eight years and used as control population (susceptible). Seeds were sowed in germination trays, which seedlings were transplanted into plastic pots of $4 \mathrm{~kg}$ capacity, nine seedlings per pot transplanted to develop three leaves (15d after transplant), when each one of the treatments application was conducted with a constant pressure of $\mathrm{CO}_{2}$ sprayer, calibrated at 29 PSI with TeeJeet 110015 nozzles and a discharge rate of $144 \mathrm{~L} \mathrm{ha}^{1}$.

A completely randomized design was conducted on three replicates per treatment. The experimental unit consisted of nine plants of $I$. rugosum populations in each pot. Treatments consisted of six doses $(0,25$, 50, $100,250,500 \mathrm{~g}$ a.i. $\mathrm{ha}^{-1}$ ) including the recommended dose (50 g a.i. ha ${ }^{-1}$ ) of bispyribac-sodium, all treatments included surfactant use in a relation of $1: 1(\mathrm{v} / \mathrm{v})$. The measured variables were height, dry weight and control percentage on the twelfth day after application. The resistance management was determined based on SAS, NLIN procedure.

I. rugosum population groups with similarities were determined through multivariate analysis of clusters resistant to bispyribac-sodium. Using the variable of dry weight, this analysis enabled to determine the similarity levels between individuals, establishing the number of different groups through dendrograms. The Ward method was used to determine groups; the variable analyzed was dry weight on each of the applied doses.

In addition, a growth reduction $\left(\mathrm{GR}_{50}\right)$ was established to determine the herbicide dose causing a $50 \%$ dry weight reduction on treated plants; $\mathrm{GR}_{50}$ was estimated through the doseresponse curve with increasing doses as per Streibig (1988) and Seefeldt et al. (1995). Based on this, resistance indexes (RIs) for the evaluated populations were determined. RIs were established at the relation between $\mathrm{GR}_{50}$ of a suspicious population into the $\mathrm{GR}_{50}$ of a controlled population (susceptible). A population is considered resistant if its RI value is higher than 2.0 (Valverde et al., 2000).

\section{RESULTS AND DISCUSSION}

\section{Problematic weeds in rice fields}

Weeds sampling in commercial fields allowed establishing, in terms of density, an average population of 540 plants $\mathrm{m}^{2}$ and an average rice population of 348 plants $\mathrm{m}^{2}$. The weed species highest frequency belonged to Poaceae family, such as Ischaemum rugosum, which was present on $100 \%$ of fields; Echinochloa colona, 82.3\%; Digitaria spp., $73.4 \%$, and Leptochloa spp. in $53.2 \%$. Cyperaceae species were found on $94.9 \%$ of fields, such as Fimbristylis miliacea, Torulinium odoratum, Fimbristylis dichotoma and Cyperus iria. Dicots were found on $93.6 \%$ of fields, within which Ludwigia linifolia, Eclipta prostrata, Hyptis capitata, Ipomoea sp., Phaseolus spp. were identified.

In Ariari region weed community, I. rugosum reached the largest population with 277 individuals $\mathrm{m}^{-2}$, representing a share of $51.3 \%$ in terms of individuals quantity, I. rugosum population is followed by sedges, with $34.6 \%$ and the broad-leaved plants group with $6.8 \%$, while species like Echinochloa colona with 11 individuals $\mathrm{m}^{-2}$ density, showed only $2 \%$. The average percentages in coverage were $55.6 \%$ and $44.4 \%$ for weeds and crop, respectively. Among the species that showed the highest I. rugosum coverage was highlighted, with an average of $29.81 \%$; followed by sedges $(9.09 \%)$, dicots $(6.04 \%)$, and E. colona $(4.86 \%)$.

The results showed that from the zone species set, I. rugosum occurs in $100 \%$ of the tested fields, with population density close to the rice plants, showing the importance of I. rugosum in the region. Based on 540 plants, corresponding to the average density in $1 \mathrm{~m}^{2}$, $51 \%$ of individuals corresponded to I. rugosum, with an average coverage of $30 \%$, therefore I. rugosum exceeds the density of other species both in density and coverage. This indicates the need of weeds early control, in order to minimize its population and coverage, reducing the possibility of interference with the crop. Rice being the most important transitional crop in Ariari region, among the components of rice production, chemical weeds control has a significant share on the 
production costs $(20 \%$ or more), specifically due to I. rugosum problematic (Delgado et al., 2009; Fedearroz, 2009).

Based on these results, weeds structure that occurs in this rice-producing region differs from I. rugosum low frequency in other rice-producing regions, such as Tolima, where this specie was found only in $10 \%$ of the evaluated fields, while Echinochloa colona was more important since it was reported with a $80 \%$ frequency in this zone (Puentes, 2003). However, Bastidas \& Ordóñez (2001) reported increments up to $20 \%$ in I. rugosum population in the zone of Meta, in an interval of three years, with a range between 200 and 650 plants $\mathrm{m}^{-2}$.

Successful colonization of lands by I. rugosum in Llanos Orientales may be due to its wide adaptability, rapid growth, and high production of seeds, staggered germination and a total cycle of 130 to 140 days, contributing to describe this specie as highly competitive in Llanos Orientales (Pabón 1990; Bakar \& Ahmed 2003; Fuentes et al., 2010). Additionally, I. rugosum has high photosynthetic efficiency because it is a $\mathrm{C}_{4}$ metabolism plant (Nabi, 1999). These features allow I. rugosum to be a highly competitive plant compared to rice, which has lower photosynthetic efficiency as $\mathrm{C}_{3}$ metabolism plant (Taiz \& Zeiger, 2006).

\section{Effect of the geographical zone}

The geographical area analysis on rice density didn't show significant differences $(\mathrm{p}<0.05)$ among zones (Figure 1); however, in zone 2 , a lower density of rice plants was found $(6 \%)$ in contrast with zones 1 and 3 . The rice planting densities used by these region farmers were around $200 \mathrm{~kg}$ of seeds per hectare, which is enough to establish populations exceeding 330 plants $\mathrm{m}^{-2}$. In this research, rice population ranged from 332 to 355 plants $\mathrm{m}^{-2}$ that being a critical interval compared to the initial I. rugosum populations, which ranged from 186 to 266 plants $\mathrm{m}^{-2}$.

Evaluation of the geographical area effect on the I. rugosum populations, allowed establishing significant differences $(p<0.01)$ among zones. The lowest population was found in zone 1 (186 individuals $\mathrm{m}^{-2}$ ), while

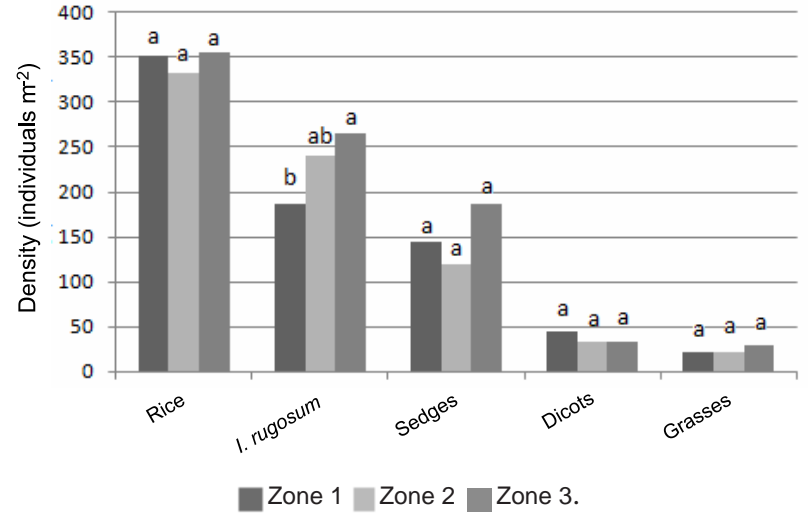

Figure 1 - Density (individuals $\mathrm{m}^{-2}$ ) of rice and weeds according to the geographical zones of Ariari region in 2008.

the highest population was in zone 3 (266 individuals $\mathrm{m}^{-2}$ ). The sedges population showed no significant differences among zones. However, the density in zone 3 (186 individuals $\mathrm{m}^{-2}$ ) was higher $23 \%$ to $36 \%$ compared to zones 1 and 2, respectively. For other grasses, populations showed no significant differences among zones, however the population in zone 3 (29 individuals $\mathrm{m}^{-2}$ ) showed increases of $28 \%$ and $25 \%$, in contrast to those found in zones 1 and 2, respectively (Figure 1).

The differences among the studied areas are given by I. rugosum densities that show lower values in zones 1 and 2 and the highest value in zone 3 . Taking into consideration that I. rugosum is the specie better adapted to wet soils, as per Holm et al. (1977) report, zones 1 and 2 should have a higher I. rugosum population, considering that these are located at lower altitudes with a higher humidity degree (Vanegas et al., 1998); however, zone 3 presented the highest population. It is unlikely that conditions described in zone 3 (higher altitude, non-flooded area by the river (Rippstein et al., 2001)), determine the increase of I. rugosum population and, probably, this increase was due to management systems that farmers practice in their fields.

\section{Effect of the rotation type}

Concerning the rotation system, 56\% of the sampled fields showed a true rotation activity: cultivation of soybean is highly 
important $(28.9 \%)$, grazing with cattle $(24.0 \%)$ and banana cultivation (2.2\%). Most of the fields on which rotation is not practiced, correspond to fields that remain fallow $(36.3 \%)$, and would be so until next year, when the soil preparation season starts for sowing at the first half of the year.

In terms of I. rugosum density variable, no significant differences were found $(\mathrm{p}<0.05)$ between rotation systems and geographical zones. However, it has been determined that, in all three zones, the I. rugosum largest population was found in fields of rice-fallow-rice rotation system, while the lowest populations were recorded in rice-soybean-rice, riceplantain-rice, and rice-grazing-rice systems (Figure 2A).

The density increase is probably due to weeds that remain in the field after harvesting and continue its development to seed production, which contributes to enrichment of the seed bank, favoring higher density with this production system. This is consistent with Bastidas \& Gómez findings (2004), which concluded that fields managed under rotation of rice-fallow-rice (for a period of two years) increased I. rugosum populations of $30 \%$ in the first year and $50 \%$ in the second year; while fields with rotation system of rice-soybean showed reduction of $I$. rugosum populations of $7 \%$ in the first year and $17 \%$ in the second year.

On the other hand, results of this research demonstrate that fields under rotation system of rice-soybean, plantain or grazing compared to fields without rotation (rice-fallow or rice-rice), show reductions of $I$. rugosum populations of $44 \%, 55 \%$ or $49 \%$, respectively. These results are consistent to those reported by Delgado et al. (2009), in which rotation with legumes contributed to reduce total re-arising populations of weeds, within rice and corn crops, in contrast to control with no rotation. Filizadeh et al. (2007), found a reduction of $63 \%$ and $80 \%$ in weeds density and biomass in rice fields of northern Iran, comparing the rice-soybean and rice-rice rotation systems for a period of two years.

Crop rotation of rice with species such as soybean or plantain changes soil preparation, sowing, fertilization, and weed management. In plantain crop, non selective herbicides are periodically used such as paraquat, glyphosate or glufosinate-ammonium, while in soybean crop, pre emergent herbicides such as metolachlor are used (cell division inhibitors) and post emergent herbicides, such as clethodim (ACCase inhibitors). Furthermore, to reduce weed populations, this activity also reduces selection pressure exerted on grasses. Weed resistance to herbicides has been characterized by the herbicides doses, the efficiency and frequency of its applications, which largely determine the selection pressure, as well as other practices such as monoculture, intensive use of herbicides, with the same mode of action and not the crop rotation implementation (Jasieniuk et al., 1996; Mortensen et al., 2000).

Coverage of rice showed no significant differences, neither among the evaluated geographical zones, nor for crop rotation within geographical zone; the value found was $26 \%$, which is considered high. In Fischer's
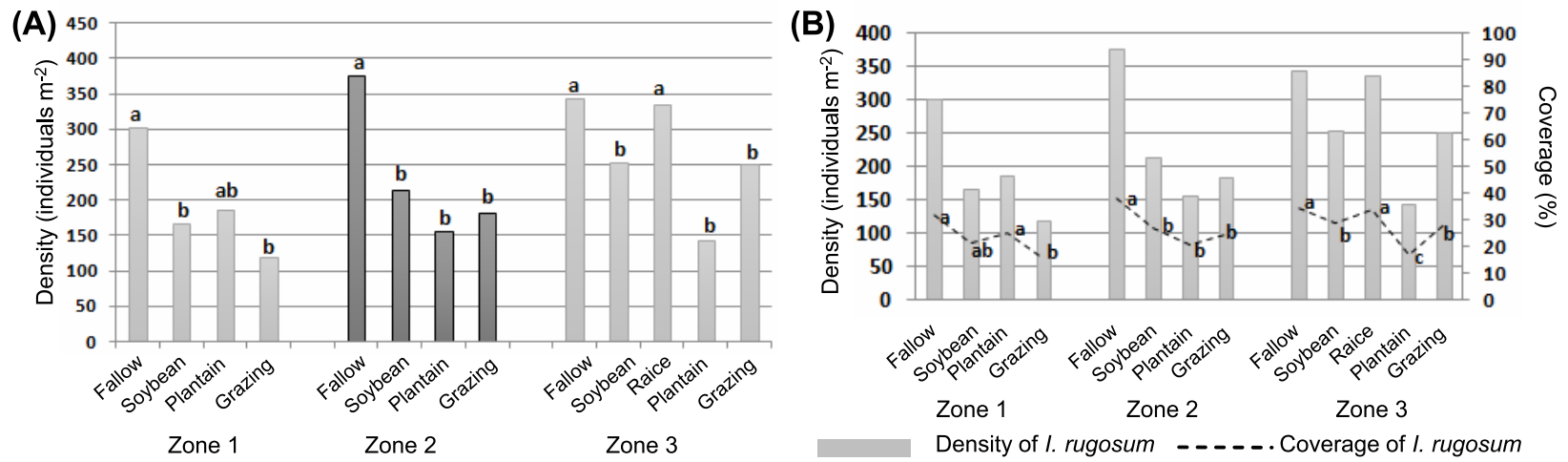

Figure 2 - I. rugosum density and coverage associated to rotation of crops in each geographical zone at first evaluation time.

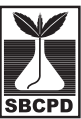

Planta Daninha, Viçosa-MG, v. 32, n. 3, p. 591-599, 2014 
research (1997) there are reports of losses with rice crop up to $40 \%$ with similar coverage than the weeds. Considering that there are weeds mild levels of interference or competence within rice crop at initial stages, the higher interference occurs in advanced stages of development (reproduction and maturation stages) (Castro \& Almario, 1990).

On the other hand, I. rugosum coverage, showed no significant differences $(p<0.05)$ among zones, in contrast to crop rotation within each geographical zone $(\mathrm{p}<0.01)$ (Figure 2B). The highest initial coverage was found in fields with rice-fallow-rice rotation, this result being consistent with results found for density variable in the same nesting.

\section{Evaluation of resistance}

The analysis of similarity grouping of dry weight component, measured after application of different doses, two population groups were obtained and susceptible control was placed in one of those groups. The populations placed on top side of the dendrogram (Group 1) showed the lowest dry weight, highest homogeneity and similarity among populations. On the bottom it could be seen that populations showed the highest dry weight (which were less affected by bispyribac-sodium applications), corresponding to $54 \%$ of the evaluated populations (Group 2) (Figure 3).

According to the cluster analysis of I. rugosum resistant populations to bispyribacsodium, two population groups were identified: (1) populations similar to susceptible control, corresponding to $47 \%$ of the population and consistent to a high percentage of fields $(86 \%)$ with rotation systems of rice-soybean-rice, rice-plantain-rice and rice-grazing-rice and (2) group of resistant populations that are consistent with a high percentage $(75 \%)$ of fields with rotation systems of rice-fallow-rice and rice-rice-rice.

Based on RIs of the evaluated I. rugosum population under application of bispyribacsodium, it was determined that $65 \%$ of the populations showed RIs higher than 2.0, which confirms resistance to the herbicide (Valverde et al., 2000). At the same time, $35 \%$ of remaining populations showed susceptibility to the herbicide $(\mathrm{RI}<2.0)$ (Figure 4).

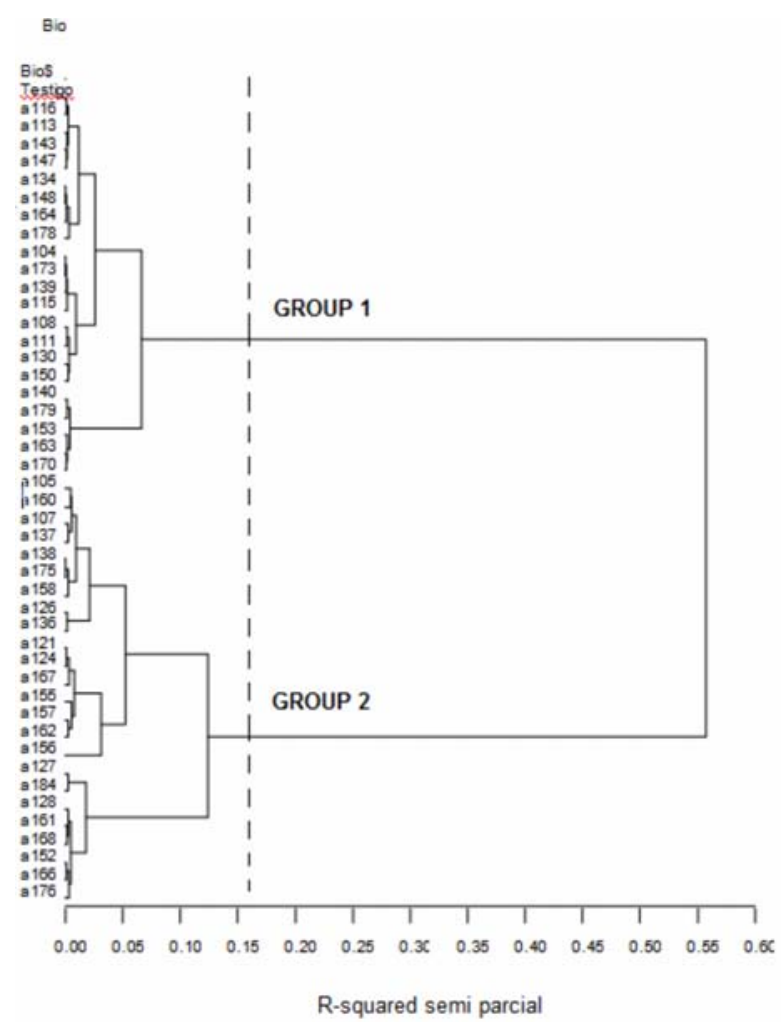

Figure 3 - Similarity among I. rugosum populations in response to bispyribac-sodium application in three zones.

In this research, a high percentage (65\%) of evaluated $I$. rugosum populations showed a $\mathrm{GR}_{50}$ that exceeds several times the $\mathrm{GR}_{50}$ of controlled field; the RI in this group ranged between 2.0 and 42.2, which demonstrates a resistance of $I$. rugosum to bispyribac-sodium at regional level. Similar results were found in a research conducted by Sangakkara et al. (2004) in Sri Lanka, Zambrano \& Espinosa (2005) and Apóstolo (2009) in Venezuela, who reported RIs exceeding 2, which confirms resistance to bispyribac-sodium herbicide (ALS inhibitor) of $I$. rugosum.

Considering the rotation system in Ariari region, these populations can be grouped in three ranges according to RI (Figure 5). Populations of I. rugosum with RIs lower than 2 corresponded mainly (92\%) to fields with rotation systems of rice-soybean-rice, rice-plantain-rice and rice-grazing-rice. Populations with RIs between 2 and 4 belong to fields with the same rotation systems (55\%), but there is an increase in the number of fields under the system of rice-fallow-rice and 


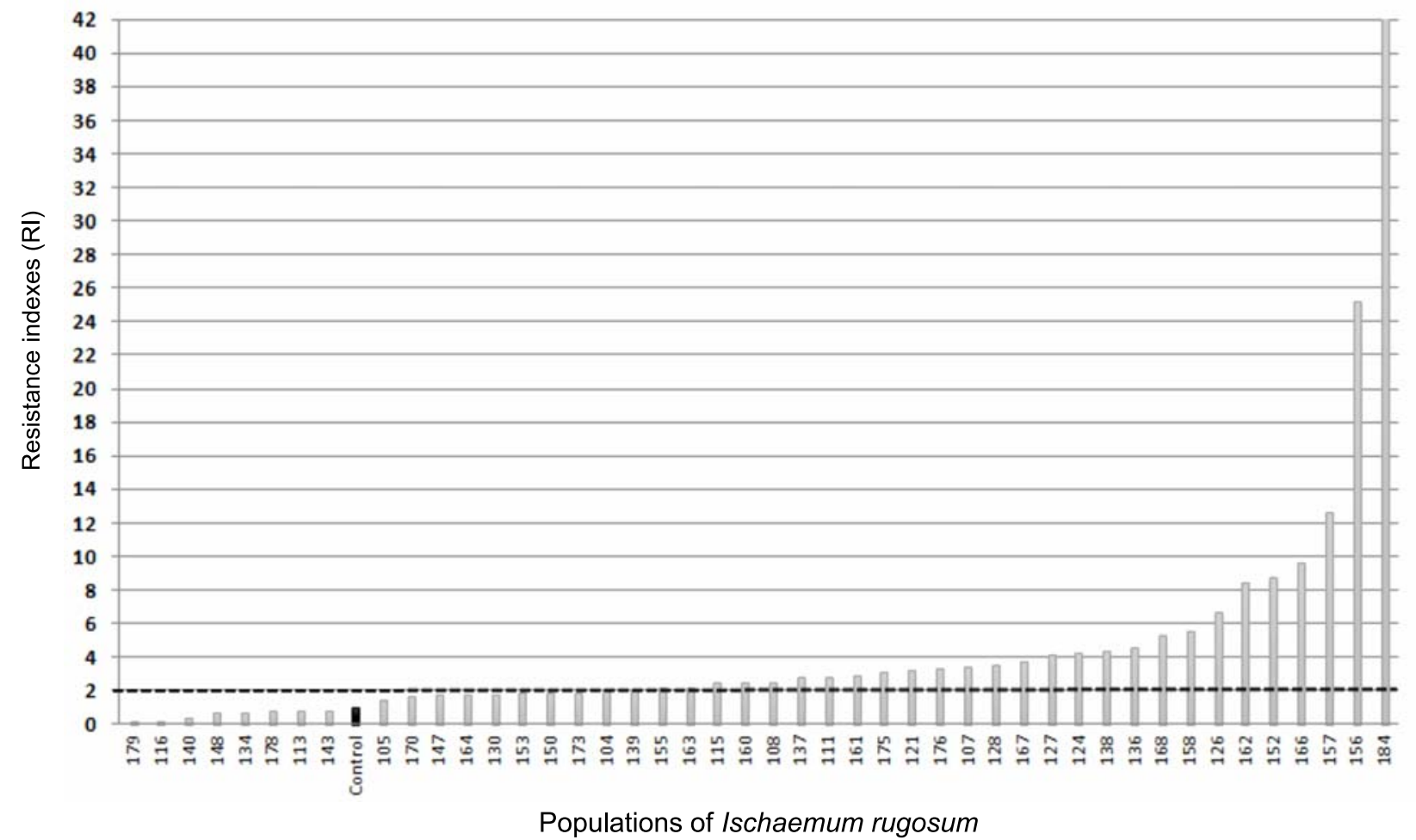

Figure 4 - Resistance indexes to bispyribac-sodium of I. rugosum populations in the studied region.

rice-rice-rice (45\%). Finally, populations with the highest RIs (above 4) are consistent to fields where higher management $(75 \%)$ of rice-fallow-rice and rice-rice-rice systems occurred. This indicates that populations with higher resistance can be found in fields, where dominant systems are fallow and continuous planting of rice, while lowest RIs can be found in fields with rotation systems (soybean, plantain or grazing). This information indicates the importance of crop rotation to reduce the selection pressure and maintain the populations with low RIs, which coincide with Filizadeh et al. report (2007), who showed that crop rotation reduces selection pressure of I. rugosum. Powles et al. (1997) and Chauvel et al. (2009) also highlight the importance of rotation to delay resistance to herbicides, as long as these products have different action mechanisms and other methods of control, differing for each crop.

The control percentages per area showed significant differences and are related to RI. In zone 3, a lower percentage of control of I. rugosum and higher RI occurred (6.8).
Zones 1 and 2 showed low RI (1.7 and 2.2, respectively) (Figure 6).

In this research, can be concluded that I. rugosum is the most important weed within the complex of weeds of Ariari region, since it presents higher frequency, density and coverage than other species in each of the evaluated areas. In zone 3, occurs the highest density of weed species, mainly I. rugosum.

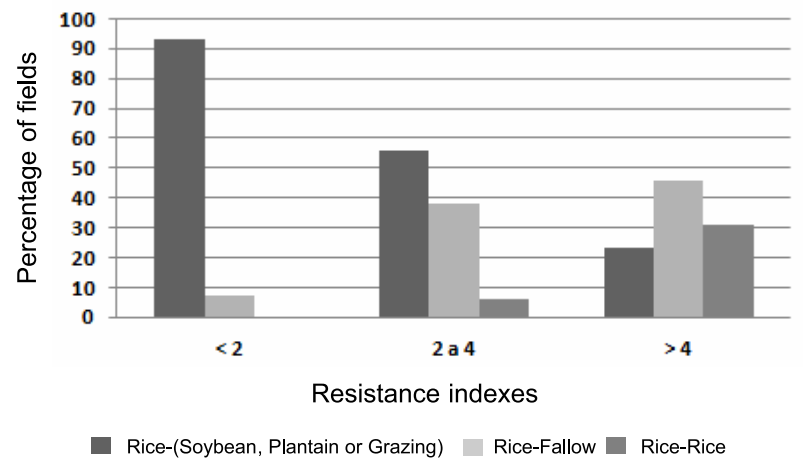

Figure 5 - Fields share according to resistance indexes and evaluated rotation systems in the studied region.

Planta Daninha, Viçosa-MG, v. 32, n. 3, p. 591-599, 2014 


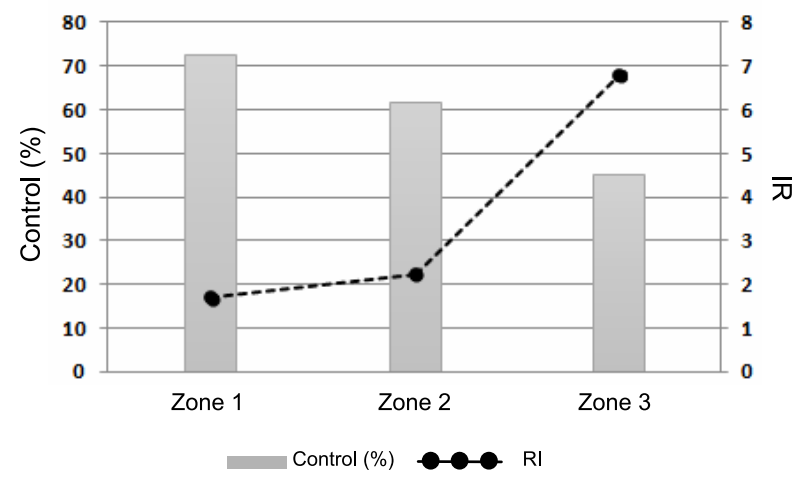

Figure 6 - RI control and values of I. rugosum populations in studied zones.

The rotation systems influence $I$. rugosum densities and coverage, the highest density of weeds being rice-fallow and rice-rice, thus increasing seed bank richness. Resistance analysis to bispyribac-sodium herbicide of I. rugosum populations in the studied zone showed two groups: (1) $65 \%$ of resistant population with RI between 2.0 and 42.0 and (2) $35 \%$ of susceptible population with RI lower than 2.0 .

\section{LITERATURE CITED}

APÓSTOLO, G. A. Evaluación de la resistencia de una población de paja rugosa (Ischaemum rugosum Salisb.) al herbicida bispiribac-sodio. Tesis de pregrado. Universidad Centro Occidental Lisando Alvarado, 2009.

BAKAR, B.; AHMED, L. Seed germination, seedling establishment and growth patterns of wrinklegrass

(Ischaemum rugosum Salisb.). Weed Biol. Manag., v. 3, n. 1, p. 8-14, 2003.

BASTIDAS, H.; GÓMEZ, N. Efecto de la incorporación de abonos verdes en la población de malezas en el cultivo de arroz en el sistema de secano. R. Arroz, v. 52, n. 448, p. 12-16, 2004.

BASTIDAS, H.; ORDOÑEZ, R. Se incrementan malezas en los Llanos Orientales. R. Arroz, v. 50, n. 433, p. 4-9, 2001.

CASTRO, R. A.; ALMARIO, O. Efecto de las malezas gramíneas en arroz. R. Comalfi, v. 17, n. 1, p. 37-41, 1990.

CHAUVEL, J.; GUILLEMIN, P.; COLBACH, N. Evolution of a herbicide-resistant population of Alopecurus myosuroides Huds. in a long-term cropping system experiment. Crop Protec., v. 28, n. 4, p. 343-349, 2009.

Planta Daninha, Viçosa-MG, v. 32, n. 3, p. 591-599, 2014
DELGADO, H. H. et al. Barbechos mejorados con leguminosas: una promisoria alternativa agroecológica para el manejo alelopático de malezas y mejoramiento de cultivo de arroz y maíz en los Llanos de Colombia. Agron.

Colombiana, v. 27, n. 2, p. 227-235, 2009.

FEDERACIÓN NACIONAL DE ARROCEROS FEDEARROZ. Subgerencia técnica e investigaciones económicas. Costos estimados de arroz riego y secano. Bogotá: 2009. 22 p. (documento interno de trabajo).

FILIZADEH, Y.; REZAZADEH, A.; YOUNESSI, Z. Effects of crop rotation and tillage depth on weed competition and yield of rice in the paddy fields of Northern Iran. J. Agric. Sci. Technol., v. 9, n. 2, p. 99-105, 2007.

FISCHER, A. Manejo integrado de malezas del arroz. En: MIP en Arroz. Caracas: Fundación Polar, FEDEARROZ, CIAT, 1997. p. 31-49.

FUENTES, C. L. et al. Malezas de los arrozales de América Latina en: Producción eco-eficiente del arroz en América Latina. Cali: Centro Internacional de Agricultura Tropical (CIAT), 2010. p. 365- 390.

HOLM, L.et al. The world's worst weed. Distribution and biology. Honolulu: The East-West Food Institute, University Press of Hawaii Honolulu, 1977. 608 p.

JASIENIUK, M.; BRÛLÉ-BABEL, A. L.; MORRISON, I. $\mathrm{N}$. The evolution and genetics of herbicide resistance in weeds. Weed Sci., v. 44, n. 1, p. 176-193, 1996.

MORTENSEN, D. A.; BASTIAANS, L.; SATTIN, M. The role of ecology in the development of weed management systems: an outlook. Weed Res., v. 40, n. 1, p. 49-62, 2000.

NABI, L. The population biology of wrinklegrass (Ischaemum rugosum Salisb.). Tesis (Doctoral) - University of Malaya, Kuala Lumpur, 1999.

PABÓN, H. A. Principios para el manejo de malezas en el cultivo de arroz. R. Comalfi, v. 17, n. 1, p. 28-36, 1990.

POWLES, S. B. et al. Herbicide resistance: Impact and management. Adv. Agron., v. 58, n. 1, p. 57-93, 1997.

PUENTES, B. Reconocimiento de la flora arvense asociada al cultivo de arroz (Oryza sativa L.) en el departamento del Tolima. Tesis (Maestría en Ciencias Agrarias) - Universidad Nacional de Colombia, Bogotá, 2003.

REZNICK, D. N.; CAMERON, K. G. The population ecology of contemporary adaptations: what empirical studies reveal about the conditions that promote adaptive evolution. Genética, v. 112/113, n. 1, p. 183-198, 2001.

RIPPSTEIN, G.; ESCOBAR, G.; MOTTA, F. Agroecología y biodiversidad de las sabanas de los Llanos Orientales de Colombia. Cali: CIAT, CIRAD, 2001. p. 8-9. 
SANGAKKARA, U. R. et al. Weeds, herbicide use and resistance in rice fields of Sri Lanka. In: INTERNATIONAL CROP SCIENCE CONGRESS, 4., 2004, Brisbane, 2004.

Proceedings... Brisbane: 2004.

SEEFELDT, S.; JENSEN, J.; PATRICK, E. Log-logistic analysis of herbicide dose-response relationships.

Weed Technol., v. 9, n. 2, p. 218-227, 1995.

STREIBIG, J. C. Herbicide bioassay. Weed Res., v. 28, n. 6, p. 479-484, 1988.

TAIZ, L.; ZEIGER, E. Plant physiology. 4. ed. Sunderland: Sinauer Associates, 2006. 764 p.
VALVERDE, B.; RICHES, C.; CASELEY, J. Prevención y manejo de malezas resistentes a herbicidas en arroz: experiencias en América Central con Echinochloa colona. San José, Costa Rica: Teresa Oñoro, 2000. 118 p.

VANEGAS, P. E. et al. Caracterización de los sistemas de producción del municipio de Granada Meta. CORPOICA, REGIONAL 8, Villavicencio - Meta. 1998. p. 12-14.

(Informe Técnico, 5)

ZAMBRANO, C.; ESPINOSA, H. Evaluación de la resistencia de biotipos de Ischaemum rugosum Salisb., al herbicida bispiribac sodio provenientes de campos arroceros de los Estados Portuguesa y Guarico. An. Bot. Agríc., v. 12, n. 1, p. 5-12, 2005. 